\title{
ANALISIS PERUBAHAN PERILAKU SOSIAL MASYARAKAT SETELAH DIBANGUNNYA TAMAN ALUN-ALUN GUNUNG GAJAH DI PEMANGKAT
}

\author{
Indah Purnama, Yohanes, Nining Ismiyani \\ Program Studi Pendidikan Sosiologi FKIP Untan Pontianak \\ Email: Jnpur07@gmail.com
}

\begin{abstract}
This study aims to determine the social behavior of the community after the construction of the Gunung Gajah Square Park in Pemangkat, Pemangkat Kota District, Sambas Regency, West Kalimantan. The general problem in this research is social behavior changes in the form of cooperation and respect for the community after the construction of the Gunung Gajah Square Park in Pemangkat. The method used in this research is descriptive in the form of qualitative research. Data collection techniques used are observation, interviews and documentation. The data collection tools used are observation guides, interview guides and documentation. There are 4 informants from the community who live in Gunung Gajah Park Square in Pemangkat, Pemangkat Kota District, Sambas Regency. Analysis of research data is presented in a qualitative descriptive manner. The results of this study indicate that social behavior in the form of cooperation and respect is still well established and after the construction of the Gunung Gajah Square Park added a sense of unity to help respect the local residents and take care of each other in the Gunung Gajah Park Square in Pemangkat.
\end{abstract}

\section{Keywords: Change, Social Behavior, Society, Taman Alun-alun Gunung Gajah}

\section{PENDAHULUAN}

Dalam setiap kehidupan masyarakat pasti selalu mengalami proses perubahan, karena pada dasarnya kehidupan sosial adalah dinamis. Tidak ada masyarakat yang tidak mengalami perubahan, meski dalam taraf yang terkecil pun, masyarakat akan selalu berubah. Pada dasarnya manusia adalah makhluk yang diciptakan sebagai makhluk dinamis, karena kedinamisannya ini manusia akan terus berkembang dan mengalami perubahan dari waktu ke waktu. Mulai dari dinamis berpikir, berperasaan, maupun berperilaku. Salah satunya adalah dalam berperilaku, Achmad (2019), "Perilaku masyarakat sangat rentan berubah setiap waktu, perubahan perilaku masyarakat dapat dipengaruhi oleh berbagai faktor, baik faktor yang bersifat internal atau yang timbul dalam diri individu itu sendiri maupun faktor ekternal yang berhasal dari lingkungan tempat individu itu berpijak"(h.8).

Menurut Abdulsyani (1995), Perubahan berarti "suatu proses yang mengakibatkan keadaan sekarang berbeda dengan keadaan sebelumnya, perubahan bisa berupa kemunduran dan bisa juga kemajuan (progress)"(h.83).

Menurut Herabudin (2015), perubahan sosial mencakup "perubahan pada norma sosial, nilai sosial, interaksi sosial, pola perilaku, organisasi sosial, lembaga kemasyarakatan, lapisan masyarakat, susunan kekuasaan, tanggung jawab dan wewenang"(h.219).

Terdapat norma yang ada sebelum adanya taman Alun-alun Gunung Gajah ini dibangun yaitu seperti, menghormati satu sama lain, menghargai orang lain dan 
bertoleransi terhadap sesama, ketika taman Alun-alun Gunung Gajah ini telah ada yaitu pada tahun 2020, masyarakat setempat merasakan perubahan yang meningkat, mengakibatkan norma yang sudah ada menjadi berjalan dengan baik, seperti rasa tolong menolong, kerja sama, semua itu dilakukan oleh masyarakat

setempat untuk menjaga taman Alunalun agar lebih bagus, sehingga menarik pengunjung untuk datang menikmati taman Alun-alun Gunung Gajah.

Perubahan yang terjadi dalam kehidupan masyarakat merupakan gejala sosial yang wajar dikarenakan manusia itu memiliki kepentingan yang tidak terbatas, perubahan perilaku sosial yang terjadi pada masyarakat tentunya disebabkan oleh beberapa faktor salah satunya, faktor dari dalam (internal) adalah faktor yang berasal dari dalam diri seseorang, faktor tersebut dapat berupa insting, motif dari dalam dirinya, sikaf serta nafsu. Ada pula faktor dari luar (ekternal) adalah faktor yang berasal dari luar diri seseorang atau individu, faktor yang timbul dari keluarga, dan masyarakat akan mempengaruhi perilaku sosial seorang individu tersebut hidup dan ditambah dengan adanya perubahan lingkungan dan kawasan yang baru yaitu Taman Alun-alun Gunung Gajah.

Perubahan perilaku pada masyarakat ada banyak sekali ragam bentuknya, ada yang bersifat positif, ada juga yang bersifat negatif, pada umumnya perilaku terjadi karena ada keinginan untuk mencapai tujuan tertentu, perubahan perilaku yang terjadi dalam kehidupan masyarakat merupakan gejala sosial yang wajar dikarenakan perkembangan zaman yang begitu pesat sehingga terjadinya perbedaan perilaku masa lalu dengan masa sekarang. Perubahan perilaku yang terjadi pada masyarakat tentunya disebabkan oleh beberapa faktor salah satunya ada penemuan-penemuan baru, media sosial yang berkembang pesat, serta adanya sebuah kawasan wisata yang juga berpengaruh atas terjadinya perubahan perilaku masyarakat.

Taman Alun-alun Gunung Gajah merupakan taman pertama yang dibangun di kawasasan Jl. Mohd Sohor Pemangkat, sehingga mengakibatkan gejala sosial yang wajar dikarenakan pembangunan taman tersebut.

Taman Alun-alun Gunung Gajah merupakan salah satu tempat wisata yang baru bagi masyarakat Pemangkat yang berada di Jl.Mohammad Sohor, Kabupaten Sambas, Kalimantan Barat. Taman tersebut berada di dekat pantai Sinam yang merupakan tempat berkumpulnya masyarakat Pemangkat yang menikmati senja, ada pula terdapat tempat duduk untuk bersantai bagi para pengunjung yang datang di kawasan ini, selain itu terdapat cafe yang disediakan oleh masyarakat yang tinggal di kawasan taman Alun-alun, serta ada masyarakat setempat yang berjualan di kawasan taman Alun-alun Gunung Gajah. Taman Alun-alun Gunung Gajah dibangun pada tahun 2020, dan sekarang merupakan salah satu tempat berkunjung masyarakat daerah Pemangkat maupun luar daerah, yang berada di Jalan Mohammad Sohor, Pemangkat Kota.

Sebelum adanya Taman Alun-alun Gunung Gajah Pemangkat, kawasan ini dulunya sangat sepi oleh masyarakat, dan kawasan tersebut hanyalah lahan kosong yang berada di tepi jalan utama yaitu Jl.Mohammad Sohor, dan ada pemukiman warga setempat yang sudah lama memang tinggal di kawasan tersebut, semenjak berdiri dan diresmikan taman Alun-alun Gunung Gajah lebih ramai dan indah, dan 
sekarang menjadi tempat untuk penyantaian yang dibuat menarik seperti dihiasi lampulampu taman yang indah.

Berdasarkan wawancara bersama Kepala Desa, pada tanggal 24 Februari 2021, Jam 09.30 WIB, penulis mendapatkan informasi bahwa setelah dibangunnya taman Alun-alun Gunung Gajah di Pemangkat, ada perubahan yang terjadi seperti perilaku sosial masyarakat yaitu masyarakat setempat saling bekerja sama dan menghargai satu sama lain. Berdasarkan wawancara yang diperoleh dari informan, pada tanggal 25 Februari 2021, Jam 10.00 WIB, penulis mendapatkan informasi bahwa sebelum dibangunnya taman Alun-alun masyarakat sekitar dulunya berperilaku cenderung individual, dan bersikap acuh, walaupun beberapa dari masyarakat yang mengungkapkan bahwa kerja sama dan saling menghargai tetap terjalin dari dalunya tetapi perilaku tersebut minim dikerjakan. Dari adanya pembangunan taman tersebut berdampak baik yaitu perubahan perilaku yang bersifat positif, diantaranya setelah dibangunnya taman Alun-alun Gunung Gajah, yaitu sikap saling berkerja sama, gotong royong, dan tolong menolong semakin meningkat, selain itu tercipta saling menghargai satu sama lain antara masyarakat setempat dan juga pada pengunjung taman.

Setelah dibangunnya taman Alunalun Gunung Gajah sebagian dari masyarakat setempat ada yang membuka cafe, berjualan makanan ringan, dan pedagang yang menjual dagangannya di taman Alun-alun Gunung Gajah, sehingga dapat membantu perekonomian masyarakat setempat, banyak aktivitas yang berlangsung di taman tersebut, pada saat sore dan malam hari banyak masyarakat Pemangkat maupun luar daerah berkunjung ke taman Alun-alun
Gunung Gajah, untuk bersua foto ataupun hanya menikmati suasana taman tersebut.

Perilaku yang nampak pada masyarakat sekitar yaitu, semakin banyak masyarakat berjualan tidak hanya masyarakat setempat tapi ada juga masyarakat lainnya berjualan menggunakan sepeda motor menjual dagangannya. Taman Alun-alun Gunung Gajah adalah sebagai salah satu faktor perubahan perilaku sosial bermasyarakat yang mengakibatkan masyarakatnya saling bekerja sama untuk membantu ketika masyarakat lainnya sedang kesusahan, serta menghormati dan menghargai orang lain yang berkunjung ke Taman tersebut.

Berdasarkan pra-riset pada tanggal 24 Februari 2021, penulis mendapatkan data masyarakat Desa Pemangkat Kota yaitu 2527, diperoleh dari data arsip Kantor Desa. Beberapa masyarakat yang bersedia peneliti wawancarai yaitu terkait dalam mata pencahariannya masyarakat yang ada di kawasan taman Alun-alun Gunung Gajah yaitu sebelum ada taman tersebut ada warga setempat bekerja sebagai buruh, sekarang setelah ada taman Alun-alun Gunung Gajah menjadi pedagang makanan dan minuman, selain itu ada warga lainnya, seorang pedagang tradisional sekarang menjadi peyalan cafe semenjak setelah dibangunnya taman Alun-alun Gunung Gajah, ada pula seorang pengepul barang bekas setelah dibangunnya taman Alun-alun beralih profesi menjadi tukang parkir, serta warga lainnya sebagai nelayan, setelah dibangunnya taman Alun-alun Gunung Gajah beralih sebagai penjaga keamanan.

Setelah dibangunnya taman Alunalun Gunung Gajah dapat disimpulkan bahwa merubah segi profesi masyarakat setempat walaupun tidak semua, serta perubahan perilaku sosial mengakibatkan 
masyarakat setempat untuk saling berperilaku positif saling menghormati dan menghargai masyarakat lainnya. Taman Alun-alun Gunung Gajah di Pemangkat banyak menarik masyarakat daerah maupun luar daerah yang berkunjung ke taman tersebut, untuk menikmati suasana bersama keluarga serta kerabat.

Berdasarkan uraian di atas, maka masalah umum dalam penelitian ini, adalah "Bagaimana Perubahan Perilaku Sosial Masyarakat Setelah Dibangunnya Taman Alun-alun Gunung Gajah Di Pemangkat"? Adapun sub masalah pada penelitian ini yakni:

1) Bagaimana perubahan perilaku sosial dalam bentuk kerja sama pada masyarakat setelah dibangunnya Taman Alun-alun Gunung Gajah di Pemangkat? 2) Bagaimana perubahan perilaku sosial dalam bentuk menghormati atau menghargai pada masyarakat setelah dibangunnya taman Alun-alun Gunung Gajah di Pemangkat?

Adapun tujuan umum dari penelitian ini adalah mengetahui Bagaimana Bentuk Perubahan Perilaku Sosial Masyarakat Setelah Dibangunnya taman Alun-alun Gunung Gajah Di Pemangkat". Adapun tujuan khusus penelitian adalah untuk mengetahui:

1) Perubahan perilaku sosial dalam bentuk kerja sama pada masyarakat setelah dibangunnya Taman Alun-alun Gunung Gajah di Pemangkat. 2) Perubahan perilaku sosial dalam bentuk menghormati/menghargai pada masyarakat setelah dibangunnya taman Alun-alun Gunung Gajah di Pemangkat.

\section{METODE PENELITIAN}

Dalam penelitian ini, peneliti menggunakan penelitian kualitatif dengan metode deskriptif. Menurut Iskandar (2009), penelitian kualitatif adalah "penelitian yang berpegang kepada paradigma naturalistik atau fenomenologi. Ini karena penelitian kualitatif senantiasa dilakukan dalam setting alamiah terhadap suatu fenomena"(h.187).

Menurut Whitney (Dalam Linarwati, 2016) metode deskriptif adalah Pencarian fakta dengan interpretasi yang tepat. Penelitian deskriptif mempelajari masalahmasalah dalam masyarakat, serta tata cara yang berlaku dalam masyarakat serta situasisituasi tertentu, termasuk tentang hubungan, kegiatan-kegiatan, sikap-sikap, pandanganpandangan serta proses-proses yang sedang berlangsung dan pengaruh-pengaruh dari suatu fenomena.

Bentuk penelitian yang digunakan dalam penelitian ini adalah penelitian kualitatif dengan metode deskriptif, dengan lokasi penelitian bertempat di Taman Alunalun Gunung Gajah, Kecamatan Pemangkat Kota, Kabupaten Sambas, Kalimantan Barat. Informan yang diambil sebanyak Empat orang yaitu satu orang selaku Tokoh Masyarakat, tiga orang selaku masyarakt yang tinggal di taman Alun-alun Gunung Gajah. Teknik pengumpulan data berupa observasi, wawancara, dan dokumentasi. Teknis analisis data berupa reduksi data, penyajian data, dan penarikan kesimpulan/ verifikasi.

\section{HASIL PENELITIAN DAN \\ PEMBAHASAN}

\section{a. Hasil Penelitian}

Observasi dan wawancara dilakukan oleh peneliti mulai pada tanggal 05 Juni 2021 sampai 12 Juni 2021 tentang analisis perubahan perilaku sosial masyarakat setelah dibangunnya taman Alun-alun Gunung Gajah di Pemangkat. Penelitian tersebut yaitu perilaku sosial di masyarakat taman Alun-alun Gunung 
Gajah terbagi 2, yaitu dalam bentuk kerja sama pada masyarakat setelah dibangunnya taman Alun-alun Gunung Gajah di Pemangkat dan dalam bentuk menghormati dan menghargai pada masyarakat setelah dibangunnya taman Alun-alun Gunung Gajah di Pemangkat. Dalam bentuk kerja sama diperoleh bahwa setelah dibangunnya taman Alunalun Gunung Gajah adalah rasa empati, saling gotong royong dan tolong menolong. Dan dalam bentuk menghormati atau menghargai diperoleh pada masyarakat setelah dibangunnya taman Alun-alun Gunung Gajah adalah tidak mengganggu hak orang lain, toleran dalam hidup bermasyarakat, dan tidak bermusuhan.

Observasi dilakukan sebanyak 4 kali pada tanggal 05 Juni 2021 sampai 12 Juni 2021, sedangkan wawancara dilakukan sebanyak 4 kali yakni pada hari Senin 14 Juni 2021 bersama JU, dan NO, dan Hari selasa 15 Juni 2021 bersama BE, dan ID.

\section{b. Pembahasan}

Perubahan perilaku sosial dalam bentuk kerja sama pada masyarakat setelah dibangunnya Taman Alunalun Gunung Gajah di Pemangkat

Perilaku sosial dalam bentuk kerja sama pada masyarakat setelah dibangunnya taman Alun-alun Gunung Gajah di Pemangkat meliputi tiga, rasa empati, saling bergotong royong dan tolong menolong.

Setelah dibangunnya taman Alunalun Gunung Gajah rasa empati pada masyarakat setempat bertambah dan semakin meningkat yakni, dapat terlihat dari penduduk setempat menjaga tutur kata sebaik mungkin pada pengunjung, menolong seseorang yang kesusahan sebagai contoh monolong orang yang sedang terluka akibat terjatuh. Dampak rasa empati kepada orang lain yang terjadi pada masyarakat kawasan taman Alun-alun Gunung Gajah, membuat berhubungan baik pada masyarakat dan pengunjung taman, rasa empati merupakan solusi penting dalam hidup bermasyarakat, karena tanpa rasa empati kedamaian masyarakat tidak akan tercipta.

Saat melakukan wawancara dengan informan JU, NO, BE, dan ID, hasil wawancara yang di dapat dari keempat informan yaitu perilaku sosial masyarakat setelah dibangunnya taman Alun-alun Gunung Gajah adalah kerja sama yang terjalin sangat baik, memberikan dampak yang positif terhadap masyarakat setempat dan pula pada pengunjung yang datang ke taman Alun-alun Gunung Gajah, yaitu terjalin dengan baik seperti tercipta rasa empati yang tinggi pada masyarakat, saling bergotong royong dalam membersihkan taman dan menjaga taman tersebut dari tindak kejahatan orang lain, saling bergotong-royong dan tolong-menolong.

Dapat disimpulkan bahwa perilaku sosial pada masyarakat setelah dibangunnya taman Alun-alun Gunung Gajah di Pemangkat salah satunya adalah kerja-sama yang terjalin dengan baik pada masyarakat setempat dan juga pengunjung yang datang di taman Alunalun Gunung Gajah. Kerja-sama ini juga sudah terjalin cukup baik dan dapat dilihat dari cara masyarakat setempat menyikapi kerja sama saling bergotong royong membersihkan taman, menjaga keamanan taman. Tolong menolong yang dilakukan masyarakat setempat, seperti membantu orang lain yang sedang 
membutuhkan bantuan. Dengan demikian kerja sama yang terjalin setelah dibangunnya taman Alun-alun ini menumbuhkan rasa kekeluargaan sesama masyarakat setempat dan juga menumbuhkan rasa peduli terhadap sesama, baik itu masyarakat yang tinggal di sekitar taman Alun-alun Gunung Gajah ataupun pengunjung yang datang ke taman Alun-alun Gunung Gajah di Pemangkat.

Perubahan perilaku sosial dalam bentuk menghargai pada masyarakat setelah dibangunnhya taman Alunalun Gunung Gajah di Pemangkat

Setelah dibangunnya taman Alunalun Gunung Gajah meningkatkan rasa menghargai perbedaan pendapat dan tidak memaksakan kehendak sendiri, dilihat dari masyarakat setempat bebas untuk berjualan dan memperbolehkan siapa saja yang ingin berjualan di kawasan taman Alun-alun Gunung Gajah di Pemangkat, dan terlihat dari masyarakat sekitar kawasan taman Alunalun Gunung Gajah membangun sikap rukun kepada teman, tetangga, dan berperilaku sopan kepada orang lain, baik masyarakat sekitar taman Alun-alun Gunung Gajah maupun dari pengunjung taman.

Toleransi pada masyarakat sekitar taman Alun-alun Gunung Gajah sudah terjalin sejak lama, setelah dibangunnya taman Alun-alun Gunung Gajah rasa toleran terhadap masyarakat sekitar dan pengunjung juga terjalin dengan baik, sebagai contoh bentuk toleransi beragama, agama apapun diperbolehkan berkunjung di taman Alun-alun Gunung Gajah dan tidak ada strata sosial masyarakat yang berkunjung ke taman.
Menurut Walzer (2017) "toleransi muncul tanpa disadari dan juga tanpa direncanakan, karena ada watak perorangan atau kelompok-kelompok manusia, untuk sedapat mungkin menghindari perselisihan"(h.20). Dengan begitu rasa toleransi setelah dibangunnya taman Alun-alun Gunung Gajah semakin meningkat untuk kesejahteraan masyarakat di Pemangkat khususnya masyarakat taman Alun-alun gunung Gajah.

Saat melakukan wawancara dengan informan JU, NO, BE, dan ID, hasil wawancara yang di dapat dari keempat informan yaitu perilaku sosial masyarakat setelah dibangunnya taman Alun-alun Gunung Gajah adalah menghormati atau menghargai satu sama lain baik sesama masyarakat sekitar taman ataupun pengunjung yang datang. Dampak yang baik setelah dibangunnya Taman Alun-alun Gunung Gajah di Pemangkat menumbuhkan rasa toleransi terhadap sesama, tidak mengganggu orang lain, dan tidak bermusuhan.

Berdasarkan uraian mengenai perilaku sosial masyarakat setelah dibangunnya Taman Alun-alun Gunung Gajah di Pemangkat bahwa menghargai atau menghormati antara masyarakat terjalin cukup baik, yaitu tidak mengganggu orang lain, toleransi antara masyarakat setempat dan pula terhadap pengunjung yang hadir, sikap yang baik oleh masyarakat setempat menciptakan tidak bermusuhan kepada orang lain, rasa sopan santun yang terjalin sangat baik di kawasan taman Alun-alun Gunung Gajah. 
Tabel 1. Data Informan

\begin{tabular}{cccl}
\hline No & Nama & Umur & Status \\
\hline 1 & JU & 50 th & $\begin{array}{l}\text { Tokoh } \\
\text { Masyarakat }\end{array}$ \\
\hline 2 & NO & 59 th & $\begin{array}{l}\text { Ibu Rumah } \\
\text { Tangga }\end{array}$ \\
\hline 3 & BE & 47 th & Pedagang \\
\hline 4 & MA & 44 th & Pedagang \\
\hline $\begin{array}{l}\text { Sumber } \\
\text { Observasi, Rabu }\end{array}$ & $\begin{array}{l}\text { Oleh } 2 \text { Pebruari 2021) } \\
\text { Penulis } \text { (Hasil }\end{array}$
\end{tabular}

\section{SIMPULAN DAN SARAN}

\section{A. Simpulan}

Berdasarkan hasil penelitian dan pembahasan mengenai perubahan perilaku sosial pada masyarakat setelah dibangunnya taman Alun-alun Gunung Gajah di Pemangkat dapat ditarik kesimpulan umum bahwa perilaku sosial sebelum dibangunnya taman Alun-alun, masyarakat sekitar taman bersikap individual, adapun saling bekerja sama itu hanya sebagian kecil dari masyarakat setempat. Sedangkan berdasarkan dari sub masalah, peneliti menyimpulkan sebegai berikut:

Perubahan perilaku sosial dalam bentuk kerja sama pada masyarakat setelah dibangunnya taman Alun-alun Gunung Gajah di Pemangkat, yaitu bentuk kerja sama masyarakat setempat, warganya jadi saling bersatu, sehingga dari hal tersebut juga mempengaruhi kualitas masyarakatnya menjadi semakin baik, menolong satu sama lain, selain itu kehidupan masyarakat di kawasan tesebut menjadi lebih produktif.

Perubahan perilaku sosial dalam bentuk menghargai pada masyarakat setelah dibangunnya taman Alun-alun Gunung Gajah di Pemangkat, yaitu perubahan perilaku sosial dalam bentuk menghargai pada masyarakat setelah dibangunnya taman Alun-alun Gunung Gajah di Pemangkat, yaitu menghargai pilihan masyarakat setempat untuk berjualan atau tidak, dan tidak ada rasa iri terhadap tetangga, terjalin harmonis pada masyarakat setempat, dan memberikan dampak yang positif yaitu membuat aktifitas masyarakat semakin mudah, dulunya kawasannya tidak ada tempat untuk objek bagi masyarakat untuk sekedar nyantai atau nongkrong tapi sekarang sudah ada.

\section{B. Saran}

Berdasarkan hasil penelitian yang diperoleh, peneliti memberikan saran sebagai berikut :

Masyarakat setempat lebih baik lagi dalam menyikapi perubahan perilaku sosial yang ada serta menjaga keutuhan nilai-nilai dan norma sosial yang berlaku di masyarakatnya.

Kepada tokoh-tokoh masyarakat agar lebih memperhatikan lagi keadaan masyarakatnya agar terhindar dari perilaku menyimpang dari nilai dan norma sosial akibat setelah dibangunnya taman Alun-alun Gunung Gajah di Pemangkat.

\section{UCAPAN TERIMA KASIH}

Terima kasih untuk pihak yang telah membantu dalam penyelesaian artikel ini. Terutama terima kasih atas dukungan dari orangtua, teman serta sahabat saya. Terima kasih juga kepada pembimbing saya yaitu Prof. Yohanes Bahari, M.Si dan Nining Ismiyani, S.Pd., M.EIL yang telah membimbing dan mengarahkan saya selama ini. 


\section{DAFTAR RUJUKAN}

Al Baghal, T., A. Jaeckle, et al. (2015). Understanding Society -The UK Household Longitudinal Study: Innovation Panel, Waves 1-8, User Manual. Colchester. ISER University of Essex.

Arthur S. Reber (2019), The Penguin Dictionary of Psychology, terj. Yogyakarta: Pustaka Pelajar.

Benzeval, M., A. Davillas, et al. (2014). Understanding Society:The UK Household Longitudinal Study: Biomarker User Guide and Glossary. Colchester, University of Essex.

Budd, S., E. Gilbert, et al. (2012). Understanding Society Innovation Panel Wave 4: Results from Methodological Experiments. Understanding Society Working Paper. J. Burton. Colchester, Institute for Social and Economic Research. 2012-06.

Enas. (2019). Sumber Dan Hakekat Pengetahuan. Jakarta : GP Press.

Fadjarajani, S. (2016). Hubungan Antara Pengetahuan dan Sikap Pelestarian Lingkungan Dengan Perilaku Wisatawan Dalam Menjaga Kebersihan Lingkungan. Jurnal Geografi. Vol.4.

Firmansyah, Mochamad Ekky (2018) Analisis Perubahan Sosial Ekonomi Masyarakat Setelah Penutupan Lokalisasi Dolly. Undergraduate (SI) thesis,
University of Muhammadiyah Malang.

Herabudin. (2015). Perubahan Sosial. Jakarta : GP Press.

Saebani, A. (2014). Perubahan Perilaku. Bandung: CV Pustaka Setia. Satori, D. \& Aan, K. (2011). Metodologi Penelitian kualitatif. Bandung: Alfabeta.

Simajuntak. (2019). Analisis Perubahan Sosial Pada Masyarakat Kota Bekasi Jawa Barat. Universitas Padjajaran.

Sugiyono. (2014). Metode Penelitian Kuantitatif, Kualitatif, dan $R \& D$. Bandung: Alfabeta.

Sjarkawi. (2019). Pembentukan Kepribadian Anak; Peran Moral Intelektual, Emosional dan Sosial sebagai Wujud Integritas Membangun Jati Diri. Jakarta: PT. Bumi Aksara. 